\title{
BARRIERS TO SUSTAINABILITY IN MANAGEMENT SCHOOLS: A BOURDIEU- SIAN EXPLANATION
}

\author{
AS BARREIRAS PARA A SUSTENTABILIDADE EM ESCOLAS DE ADMINISTRAÇÃO: \\ UMA EXPLICAÇÃO BOURDIEUSIANA
}

Recebido em: 10/01/2018 - Aprovado em: 04/05/2018

Avaliado pelo sistema double blind review Editor Científico: Edson Sadao Iizuka DOI 10.13058/raep.2018.v19n3.955

\author{
BRUNO DE SOUZA LESSA brunolessa85@yahoo.com.br \\ KELLY FABIANE SPIER \\ LUIS FELIPE MACHADO DO NASCIMENTO \\ Universidade Federal do Rio Grande do Sul
}

\begin{abstract}
The aim of this theoretical paper is to ascertain, through Pierre Bourdieu's conceptual apparatus, the barriers preventing effective sustainability in Management Schools. In this sense, this paper argues that barriers emerge because of a dissonance between students' habitus and sustainability principles and their related contents. Such processes would not allow them to be aware of and recognize the contents related to sustainability in the same way as those based on neoclassical economic thought, which takes root in their minds as they are constructed, produced and reproduced across the most diverse standard environments of socialization. The focus was, therefore, to explain these barriers in the light of Bourdieusian epistemology, showing the dynamics that make them appear and providing an analytical instrument to enable a better understanding of the social relations that foment them.
\end{abstract}

Keywords: Sustainability; Management Schools; Barriers; Bourdieu.

\section{RESUMO}

O objetivo deste ensaio teórico é desvelar, a partir do aparato conceitual fornecido por Pierre Bourdieu, os condicionantes de barreiras para a efetivação dos princípios da Sustentabilidade em escolas de Administração. Este ensaio relaciona as barreiras que emergem para a Sustentabilidade às dissonâncias entre o habitus de alunos e os conteúdos relativos à sustentabilidade a eles transmitidos em sala de aula. Parte-se do pressuposto de que o habitus dos alunos, compreendido como sistema de disposições, conjunto de esquemas de classificação, percepção, apreciação e ação, construído no decorrer dos mais variados processos de socialização, não os permitiria reconhecer como legítimos os conteúdos relativos à Sustentabilidade da mesma forma que ocorre com aqueles conteúdos lastreados pelo pensamento econômico neoclássico. Este último encontra-se mais fortemente inculcado nas mentes dos alunos à medida que é construído, produzido e reproduzido nos mais variados ambientes-padrão de socialização. Portanto, o escopo desta reflexão consiste em explicar tais barreiras à luz da epistemologia bourdieusiana com ênfase nos condicionantes que as fazem emergir. Palavras-chave: Sustentabilidade; Escolas de Administração; Barreiras; Bourdieu. 


\section{INTRODUCTION}

Over the past decades, there has been an intensification of environmental problems and, as a result, there has also been a growing concern about issues related to them. The imperative of dealing with such issues emerged in contemporary capitalist society through the search, for instance, for theoretical and practical solutions in the most diverse realms of human activity. From production to management, sustainable development or sustainability principles, such as the balance between economic development, reduction of social inequalities and minimization of the exploration of natural habitats (ELKINGTON, 1998) have become almost mainstream in recent times.

Considering the managerial field, it is possible to state that companies that act in a more responsible way are very likely to have managers who were educated on new paradigms, that is, forms of knowledge taking into account visions of an alternative world, where profiteering at any cost or perspectives of endless economic growth are not the only possible scenarios. Thus, educational spaces such as schools of management can be regarded as key for the construction of organizations guided by sustainability mottos as the ones from the "triple bottom line", for instance (ELKINGTON, 1997), with managers educated in these spaces (and principles) more likely to engender actions towards the solution of contemporary environmental problems (BRUNSTEIN; JAIME; CURI; D’ANGELO; MAINARDES, 2015).

Nevertheless, previous studies performed nationally and internationally presented an empirical setback. Although sustainability principles should appear as imperatives to be studied and applied carefully, in fact, what really has been taking place is the emergence of barriers for students, staff and faculty members to incorporate and internalize norms and values related to such principles (GELI; LEAL FILHO, 2006; KOPNINA; MEIJERS, 2014; STUBBS; COCKLIN, 2008; BARTH, 2013; FIGUEIRO, 2015; PALMA; 2015; SCHUTEL, 2015; TIANA; MORILLA; CARRERA; RAMENTOL, 2017). These prior studies have stressed the presence of obsta- 
cles coming from different social actors for the necessary changes in the "rules of the game" needed to make sustainability a core value in management schools. This diachrony led to the reflections and argument underpinning this paper.

We focus on students' habitus (BOURDIEU, 1992, 1989, 2007) to argue that the diachrony between their matrix of mental schemes of perception, evaluation and action and the contents related to sustainability principles engenders the barriers seen for such issues in management schools. To construct this argument, we hypothesize that students' habitus would indeed hinder them from recognizing sustainability-related content as legitimate, compared to those founded on neoclassical economic thought.

In this sense, we acknowledge that there are practical mechanisms that contribute reflexively for the social construction of institutional, pedagogical and curricula-related obstacles as highlighted in the theses by Figueiró (2015), Palma (2015) and Schutel (2015). These authors found and highlighted different kinds of barriers to sustainability in management schools and proposed creative solutions. Notwithstanding their efforts, our aim here is not to provide another solution, but to understand how these barriers take place, with the assistance of Pierre Bourdieu's conceptual apparatus. In fact, we started our reflections by paraphrasing one of Bourdieu and Passeron's $(1992,2014)$ earliest propositions, that is, the formal schooling system, as objectified in regular business schools, is utterly pregnant with the reproduction of a determined social order.

Following this perspective, we suggest that there is a dissonance between the social relations historically incorporated by students (social agents we chose to attach here for their quantitative and educational relevance) and aspects in line with the principles of sustainability. There is a resulting disharmony amid students' embodied mental schemes and what they see in classroom. Such disharmony leads to a "reduction" of interest in some content, which happens not necessarily because of methodological factors, but due to a misrecognition of what is being learnt. In Bourdieusian terms (BOURDIEU, 1991), the cultural capital students possess would not 
converge to the ones required in classroom practices or, in further analysis, their habitus does not acknowledge certain issues as legitimately as others.

This paper's contribution lies in its subsidy to discussions on how these barriers appear and which strategies should be developed to overcome them. We recognize the potential of Bourdieu's conceptual apparatus to debate the most diverse theoretical and empirical issues regarding education as a whole. Thus, in order to unveil and understand the dynamic mechanisms of production and reproduction engendered within any level of the formal school system, concepts like habitus, field and the typology of capitals (as well as their uneven distribution) are rather useful.

Nonetheless, it is imperious to stress that our objective here is not to present or discuss the barriers to sustainability in higher education in themselves or to provide a sort of genealogy, just as it is definitely not to offer any structuring solution to these obstacles. In truth, our focus is more modest, but no less bold, insofar as it employs Bourdieu's epistemology and his reflexive sociology (BOURDIEU; WACQUANT, 1992) to uncover the very basis underpinning these barriers rather than reviewing them.

This paper is divided into five sections, counting from this introduction. The next section presents our arguments and provides Bourdieu's theoretical inputs to facilitate the understanding of the third one, which introduces our operational definition of sustainability and makes clearer the difference between ours and other definitions. Furthermore, the third section makes a brief exposition about the importance of education for the field of management. Afterwards, the fourth section uses the Bourdieusian concepts to explain how the obstacles to sustainability arise. Finally, our concluding remarks offer other thoughts and questions for further studies. 
THE FORMAL EDUCATION SYSTEM AS AN INSTRUMENT OF SOCIAL REPRODUCTION AND HABITUS CONSTRUCTION

In order to discuss the barriers to sustainability within management schools, it is necessary to question the role of the school system in its entirety. As we have mentioned before, our argument draws on the early works of Pierre Bourdieu and Jean-Claude Passeron $(1992,2014)$ inasmuch as they advocated the provocative idea (following a rather Durkheimian perspective) that the formal school system is actually an instrument for the reproduction of a consolidated social order. For the sake of our argument, it is the power of structured dispositions, behind such a reproductive system, that brings about, in general terms, the barriers themselves.

By exposing the school system as one of social reproduction, these authors broke away from what they called the "Jacobin illusion", i.e., the idea that schooling by itself would be enough for individual or social transformation. In their argument, schooling is still central, but for the role this societal reproductive engine has as an apparatus of symbolic violence. The school and its agents are able to impose specific meaning attributions and, as they legitimize them, add a further symbolic force to social relations (BOURDIEU; PASSERON, 1992).

Bourdieu and Passeron affirmed that if one tries to deny this axiom on symbolic violence, one also denies the possibility of making any social science. It is exactly this axiom on the imposition of legitimate meanings, which, at the same time, states the autonomy and the relative dependence of symbolic relations towards the relations of force that lie in the very constitution of the social world. There are no relations of force, no matter how mechanical and coercive they seem to be, that do not exert a symbolic effect. Moreover, denying this axiom leads, for example, to the naïve idea that there is a creative freedom emanating from individuals or groups, linked with fully autonomous symbolic actions independent of their practical objective conditions (BOURDIEU; PASSERON, 1992).

The actions engendered within this formal system cannot be understood as encompassed exclusively in it, but as having branches connected 
to all previously educated members of a social formation. By highlighting this feature, Bourdieu and Passeron $(1992,2014)$ stressed the pedagogical role of family members as well as other institutionalized educational agents (meaning the ones who were somehow legitimized to educate). Thus, the pedagogical action is one whose meaning is widely recognized whereas it contributes for the maintenance of the dominant culture through the reproduction of the structure of relations of force.

Management education, as well, cannot be disregarded as part of our social formation; thus, symbolic relations of reproduction are inherently intertwining. Nonetheless, it is not our focus, here, to identify these dominant groups and which contents, exactly, are more interesting to be seen in management courses. However, the refracted power of these dominant groups is what enables them to introduce their contents as priorities to be studied, considering the objective context of social relations wherein they take place.

The correspondence between material and symbolic interests of certain groups and classes objectifies itself in the school system and, in effect, it tends to reproduce the distributive structure of the different forms of capital they happen to possess (BOURDIEU; PASSERON, 1992). For instance, let us take the relations of force amid groups in a management school and outline a departmental meeting in which professors of courses related to marketing or finance are more likely to have greater bargaining power to position their demands as more legitimate. They will turn out to express this relative power by being capable of pushing for more space and time for their courses in the syllabus. These relations are a refraction of the dynamics established in the academic field (and in the social world) by the disciplines they teach and study (BOURDIEU, 2004).

Interestingly, the structured and structuring dynamics of these social relations are so incorporated in almost all social agents that they even seem to be "natural", as if these processes were the very essence of an educational organization, for example. In effect, ideologies as well as material and symbolic relations of power become taken for granted. The practical reasoning underlying these dynamics collaborates to this phenomenon as 
it helps to build this false perception of naturalness (BOURDIEU, 1989). Following this perspective, pedagogical emitters such as professors and researchers, for instance, are regarded to be worthy of exercising their work because they have been vested with symbolic elements which form a set compounded by their speech, lifestyle and dress codes. These elements, along with their titles, legitimize these emitters to carry on their work in the different strata of the schooling system.

Another element of the Bourdieusian apparatus that needs to be introduced at this moment is the concept of field (which will be further explained in another section of this paper). Although there can be established a competitive relationship between the strata regarding their struggle for legitimacy within the system as a whole, each stratum (elementary school, high school or higher education) is relatively autonomous. In this sense, they work as social fields, in themselves, with relative autonomy and holding their proper rules. In spite of such autonomy, all of them are pressed by a relative dependence of homologous struggles that take place among social groups or classes (BOURDIEU, 1998a). For example, the conflicts between faculties in a department reflect the struggle that their disciplines have in the broader social world. In metaphoric terms, it would be what happens between the homo economicus rationale vs. the man preconized by the principles of sustainability.

Furthermore, it is pertinent to emphasize that to be recognized as worthy, emitters' legitimacy has to be promptly taken for granted by students. The contents he or she teaches, as well as a specific "posture", are the elements that provide a professor with the legitimacy students need to supply for the learning process to be successfully accomplished. That is, learners must be willing to receive and internalize the messages professors are communicating to them (BOURDIEU; PASSERON, 1970).

For Bourdieu, the educational field functions as a market, a place where social agents confer convertible symbolic values to all sorts of practices. The more unified a market is, the more groups and classes will forget the non-value of their own culture when compared to the dominant one. This logic can be further expanded to the academic field, insofar as 
the mechanisms that compose these dynamics are strengthened sanctions coming from the job market, symbolic sanctions from cultural markets and, of course, from the power immanent to tests and verdicts. However, dominant and dominated groups are both targets of this inculcation process that culminates in the misrecognition of the objective truth about the culture reputed as legitimate (BOURDIEU, 1998b).

The pedagogical work occurring in the multiple levels and in agents' schooling experiences aims to produce a habitus, i.e., a transposable and durable set of dispositions that are the ultimate product of all inculcation processes taking place within the educational system (BOURDIEU, 1992, 2007, 2014; BOURDIEU; WACQUANT, 1992). In this regard, the success of any pedagogical work might be measured by how much it can engender durable practices in accord with the principles inculcated. Another form of measurement is through how much it can generate practices following the same conformity in different fields, foregrounding its durability and transferability. Moreover, the habitus has the key characteristic of perpetuating itself even after the pedagogical work has ended, being capable of preserving practices related to the principles interiorized in it (BOURDIEU; PASSERON, 1992, 2014).

The existence of the habitus objectifies itself, for example, as one seems to "repeat" attitudes learnt in his or her early years of education, which, in their turn, actualize not only physical practices that were taught in previous educational processes, but also symbolic aspects, inasmuch as any practice is permeated by principles that serve as their epistemic base. As a result, a person educated in utilitarian, self-interested or profit-maximizing principles is likely to behave in alignment with these ideas even as he ages.

Bourdieu and Passeron (1992, 2014) affirmed that this pedagogical work has permanent results. The dispositions it creates can be only repressed or transformed if another creative process takes place. Irreversible dispositions must be replaced by other irreversible dispositions. Thus, a teaching effort to inculcate new principles will have to struggle with previous pedagogical work established by students' families and society as well 
as prior schooling experiences. In addition, it is noteworthy that professors within the system serve as interchangeable specialized agents invested with homogenous formations in order to ensure a specific regulated teaching form (BOURDIEU, 1998c).

Therefore, the habitus, the aforementioned result of all pedagogical work, can be defined as an array of dispositions that integrate ones' past experiences, functioning at every moment as a matrix of perceptions, evaluations and actions. The habitus enables the performance of an infinite number of differentiated tasks insofar as the schemes that the habitus expresses itself as the mediating principle that makes the correspondence between individuals' practices and their social conditions of existence (BOURDIEU, 2007). Hence, this is why the habitus can be regarded as a conceptual instrument to understand certain homogeneity in the disposition and preferences of groups and individuals coming from a similar social trajectory.

Despite the fact that it is a kind of embodied history, the habitus cannot be considered an unchangeable crystalized memory, incapable of any modification. Inasmuch as it as system of dispositions, it is built and rebuilt continuously and dialectically. It remains open and exposed to new experiences. Regarded as such, the habitus works also as a stock of incorporated relationships put in practice from the contextual stimuli from a field. Because of these reflexive properties, this system of dispositions leads to a certain degree of awareness about its practices, but within structured and unstructured social and historical conditions (BOURDIEU, 1992, 2007, 2014; BOURDIEU; WACQUANT, 1992).

Therefore, the concept of field is essential to understand the social world through Bourdieu's theoretical perspective because of its intrinsic relation with the habitus. To explain social agents' practical adjustments, it becomes imperative to introduce these two interweaving concepts. This relationship is better scrutinized in the next section. 


\section{THE SOCIAL FIELDS}

The concepts of habitus and field might be considered analogously as bundles of social relations. On the one hand, a field is formed by an array of historically objective situated relations, underpinned by different kinds of capital, i.e., particular forms of power. On the other hand, the habitus is composed by the gathering of historical relations stocked in the individuals' bodies in the format of mental and corporal cognitive, apprehension and action schemes (BOURDIEU; WACQUANT, 1992).

For definitional purposes, we can assert that fields are social worlds and, as such, hold relative autonomy and demand from those involved in it a practical knowledge of their operational laws. This knowledge emanates from a habitus obtained via the socialization practiced within this specific field or through chronologically anterior socializations. It is in the relation with a field that the habitus establishes itself as a socialized and structuring corpus, incorporated with the structures of a determined social world. These immanent structures are products of the historical work of subsequent generations and thus, a field frames not only the actions people perform in it, but also their perceptions in this regard (BOURDIEU, 1996).

The variation of the relative autonomy in any field occurs in accordance with the higher or lower social gravity its internal forces possess. In this sense, these forces define what is legitimate or not. Another point to be brought forward is that this relative autonomy sets the conditions regulating the struggles taking place. Beforehand, agents are required to accept the laws of this social world and abide to it as they are, at the same time, the condition to enter and the entitlement to stay. These shared norms enable these agents to try to settle what is to be known and recognized as worthy (BOURDIEU, 1989).

As a theoretical construct, the field remits to dynamics of regularity and homogeneity in the social world, that is, a field presents the conditions for its reproduction within its own development. This reproduction is engendered through the formation, in educational terms, of all newcomers. Formative processes happening in schools, universities and in formal as 
well as in informal study groups, for instance. Moreover, besides these organizations, there are other consecrating institutions that coordinate what should be valued or not. All consecrating institutions are also constitutive elements of a field and they help to foster its dynamics insofar as they determine the forms of selection, evaluation and sanctions (BOURIDEU, 2004).

Furthermore, the positions agents occupy in the socially structured space affect the field, but these positions are affected recursively by the field's logic. Such positions are organized by the differentiation of closer rivals, by their efforts to reduce competition and their willingness to establish power monopolies in particular sectors, which build up inasmuch as these agents interact with one another (BOURDIEU, 2003, 2007). In effect, all the efforts are oriented not only for the establishment of competition criteria, but also for canons that regulate belongingness. Nonetheless, the effectiveness of these efforts is conditioned by specific contextual elements, which can be known only empirically (BOURDIEU; WACQUANT, 1992; BOURDIEU, 2003).

About these disputes, they tend to intensify because the value of the capitals all in-field agents hold are constantly matter of questioning. The fundamental point here is the production and reproduction of power itself. For Bourdieu (1996), power is not satisfied with simply existing as such, i.e., as a punctual unjustified coercion, it is imperative to ground its existence somehow and, whenever possible, to mask its arbitrariness.

Furthermore, the mobilization of all types of capital and the inherent struggle anteceding this mobilization take place because all fields are vested with interests. Being interested in participating in the academic field, for example, admits tacitly that this game deserves to be played and it has desirable awards. These socially constructed interests exist only if related to the social space where some elements are important whereas others are not. This negation is seminal insofar as it is what objectively provides all agents with the common identity principle that make them fight for what is at stake in the game (BOURDIEU, 2004, 2007).

These Bourdieusian formulations have contributed to social sciences (and to our proposal) as they unveil the deep underlying mechanisms of 
power. It demonstrates that, even if we picture it cheaply as a superstructure operating over agents' heads, the field as a theoretical construction is not deterministic at all inasmuch as they have a relative autonomy of the broader field of power. In addition, it offers the possibility to study the strategies agents formulate and to analyze the interests they put in dispute through the mobilization of their resources of power, that is, their types of capital (MISOCZKY, 2003).

Henceforth, the types of capital appear as another central element to understand Bourdieu's conceptual apparatus once it has a clear theoretical relation with the concepts of habitus and social fields. They contribute to this paper aiding to understand how historical relations incorporated by students act over their generative schemes as well as how it allows discussing the social positions agents occupy. This contribution makes it necessary for us to introduce briefly the types of capitals, focused on in the next section. 


\section{FORMS OF CAPITAL}

For Bourdieu, the social world is made of accumulated history and cannot be reduced to a sort of balance among autonomous agents insofar as they are endowed with capitals, direct products of social labor. Thus, following Marx, Bourdieu (1985) defines capital as accumulated labor that might be privately appropriated by an agent or a group of them, providing these individuals with "social energy". Nonetheless, the French sociologist moves on from the Marxian proposal. He agrees with the idea that capital is indeed a socially recognized source of power, but it portrays itself through different ways in society (BOURDIEU, 1985).

Bourdieu expands capital to beyond its original economic form, despite the fact that he concurs with the primacy of the economic form in social life. In truth, Bourdieu suggests a general economy of practices to contemplate capital in its totality. Such economy would encompass all dissimulative labor that enables the conversion of all forms of capital in distinct realms of society, which ensures both material and symbolic profits to its holders (BOURDIEU, 1985).

Regarding its typology, capital can appear in three main forms. The economic one, which can be converted immediately into money and institutionalized via rights of property. Secondly, the cultural form that is often convertible into economic capital and might be institutionalized by educational qualifications. Thirdly, social capital, a form constituted of social obligations linked with the networks agents establish in their trajectories (BOURDIEU, 1998a).

According to Bourdieu (1985), cultural capital may exist in three main states: the incorporated, i.e., represented by lasting dispositions in agents' minds and bodies. In the objectified state, that is, cultural goods such as paintings, books, musical instruments, dictionaries and so on. Moreover, in an institutionalized form, objectified through educational qualifications that warrant entirely original properties about the cultural capital they represent.

The incorporated state presents itself through the different ways an agent was "cultivated" in the educational sense of the term. This state of 
cultural capital presupposes an inculcation and assimilation process as well as a cost of time to be personally invested by the agent himself. This investment may not always occur consciously because - depending on the historical period, society and social class - inculcation does not necessarily take place deliberately. This is the reason why incorporated cultural capital remains marked by its anteceding conditions, visible through markers highlighting its class characteristics and region where it was incorporated, for instance.

Furthermore, cultural capital attains the very interesting feature of having its methods of transmission and acquisition more easily disguised than the ones generating economic capital. This disguise transforms it into a legitimate competence, thus, functioning as a form of authority due to this dissimulation effect (BOURDIEU, 1998b). The symbolic efficacy of cultural capital relies on its logic of transmission, objectified mainly via family socialization. First, because of the necessary time to happen, the transmission depends on the cultural capital incorporated by all family members. Second, because initial accumulation, a precondition for faster and easier transmission, happens only for children of families endowed with the strongest cultural capital. In these cases, the period of accumulation is actually proportional to the whole period of socialization (BOURDIEU, 2007).

In its objectified state, cultural capital is portrayed through goods such as books, comics, paintings or films, but it cannot be reduced only to tangible goods. Bourdieu (1985) emphasizes that, despite being presented in an apparently coherent universe, objectified cultural capital is also a product of historical actions and it has its own laws just like the languages it illustrates.

Institutionalized cultural capital is objectified by academic qualifications, that is, certifications of competence that confer to their holders legally recognized and socially constant value. These titles operate a kind of "social alchemy", resulting in a form of capital that possesses a relative autonomy of its owner. Inasmuch as it confers institutional recognition to the cultural capital possessed by any agent, academic qualifications also enable a comparison of all qualifications and even to replace these individu- 
als. Furthermore, such recognition allows the establishment of conversion rates between cultural and economic capitals as it grants monetary values to specific forms of academic capital. However, the material and symbolic profits ensured by academic qualifications keep being conditioned to their scarcity in society (BOURDIEU, 2007).

Social capital is, in its turn, the gathering of all accessible resources (real and potential) connected with the possession of networks of relations. It is linked to belonging to a determined group, belongingness that confers to each member of the group properties related to the capital possessed by the collective. It creates a credential that provides "credit" in the most varied meanings of the word. Hence, the volume of capital of an agent is dependent on the width of the contact network he or she can mobilize effectively and of the volume of cultural capital each individual to whom he is connected has (BOURDIEU, 1998c).

This network of contacts is also a product of individual and collective, as well as conscious and unconscious, strategies oriented to settle or reproduce social relations that are directly usable in the short or long term. These strategies aim to transform contingent relations, like the ones we have in workplaces, neighborhoods or kinship, in relations that imply subjectively felt obligations (such as feelings of gratitude, respect and friendship) or institutionally assured ones. Thus, the reproduction of social capital surmises an everlasting sociability effort, that is, a continuous series of exchanges (and expenses of time, energy and economic capital) in which the recognition of these connections is permanent (BOURDIEU, 1998a, 1998b).

For Bourdieu (1985), the convertibility of these different types of capital is the aim to which all strategies for their reproduction focus. This convertibility permits us to distinguish one type of the other and perceive their distinctions according to their possibilities of reproduction, taking into account how easy it is to transmit them. The French sociologist affirms, in this regard, that the other kinds of capital can be derived from the economic one, but only over the cost of a great transformation effort needed to produce of a sort of power that works only in a specific field. 


\section{WHY ARE THERE BARRIERS FOR SUSTAINABILITY IN MANAGE- MENT SCHOOLS?}

The change to an allegedly sustainable future would be based on individual participation and a continuous learning process that would intertwine, in its turn, all levels of social relations and move on throughout the rest of individuals' lives. In addition, such learning, mediated by constant interactions, is also one of construction of adaptive patterns of thinking, understood as the capability to develop skills enabling people to operate with success even in situations of high uncertainty. These operational mechanisms would take into account the relevance of a kind of development that would balance economic profiteering, social responsibility and respect for the environment (WARBURTON, 2003; GELI; LEAL FILHO, 2006; STUBBS; COCKLIN, 2008; BRUNSTEIN; JAIME; CURI; D'ANGELO; MAINARDES, 2015).

In this regard, Figueiró (2015) highlights the role of education in management, because of its double influence. First, it holds an undeniable impact on the context of enterprises as it might be consonant with companies' demands and push specific agendas into their field. Second, higher education institutions qualify the offer of managerial workforce that enterprises demand, thus, management education ends up being an important issue for companies, as well as to academia.

Furthermore, considering the Brazilian scenario, it is noteworthy that the role of education for a more sustainable society would lie in the fact that management schools (as universities in general) could be understood as abiding by a "social contract". In this sense, society would invest certain prerogatives like autonomy, resources and legitimacy expecting to receive knowledge to build a "better" social organization according to a certain perspective. For instance, if promoting sustainability is a societal objective, higher education institutions would be compelled to promote not only environmental improvements, but also to imprint sustainability in their ways of teaching, researching and developing their operations (BOYLE, 2004). 
Moreover, the relevance of business schools can be sustained in five arguments. First, if management is to be changed, the way managers are educated must be modified. Second, inasmuch as practices related to sustainability are incorporated to organizations it is necessary for them to be brought into formal education. Third, universities would be late if compared to other private organizations once the latter would be more concerned about climate change and responsive to related social claims. Fourth, to foment more sustainable organizations, it would be imperative to present new concepts to managers at the most diverse hierarchical levels. Finally, if students are not taught about or do not comprehend the impact of their actions in the future, they will not be able to engender the paradigmatic transformation the world requires (JABBOUR; SARKIS; JABBOUR; GOVINDAN, 2013).

Nevertheless, propositions of social transformation tend to face a certain level of resistance. Kopnina and Meijers (2014) listed five challenges linked with educating managers with principles of sustainability. The first one would be the lack of consensus and clear objectives on what sustainability as a phenomenon aspires to achieve. Second, the idea of balance between the economic, social and environmental realms would be highly questionable due to this lack of consensus. Third, the challenge to clarify what priorities for development would fit for developed and underdeveloped countries. The fourth challenge would be the existence of deep differences within each country regarding local and national interests. Lastly, the arguments coming from stakeholders such as governments with neoliberal agendas, large companies or NGOs with great power and influence that interact with one another and pose paradoxical and contradictory objectives.

These challenges are objectified in the barriers mentioned by both Rohweder (2004) and Lozano (2006), who foregrounded five obstacles to consolidate sustainability at individual and organizational levels. Firstly, Rohweder (2004) brought forward the role of individualistic and personal approaches conditioning the inclusion of topics related to the principles of sustainability in curricula. Second, compartmented forms of thinking and acting would be responsible for the lack of belongingness perceived in and 
with the area; as a result, people would give a secondary importance to it as they would seek to first defend their areas of interest. Lozano (2006) continues with these two ideas and suggests three other organizational factors such as conservatism and resistance to change. For instance, the creation of extra work for the faculty committed with operationalizing these principles. Finally, the shortage of relevant and complete information, as well as the scarcity of methods about how to incorporate sustainability principles in individual activities.

Palma (2015) unveils that the main barriers for sustainability in business schools are strongly linked with our argument, that is, there is a diachrony between the underlying principles of contents that most agents expect to learn in business schools and their previously acquired mental schemes attained in prior socialization processes. This diachrony emerges in the constant struggle between new propositions about the social world and the historical relations incorporated, manifested and articulated through agents. Although the author did not employ the Bourdieusian conceptual apparatuses to list the barriers she revealed, it is possible to adapt her list and, utilizing a homology rationale (BOURDIEU; WACQUANT, 1992) to realize that the barriers she detailed might be related to the argument we have brought forth. To better illustrate this rationale, Figure 1 adapts the list present by Palma (2015) in her thesis, but instead of classifying these obstacles as barriers for sustainable transformative learning in business schools, we expand the author's original proposition and enroll them as obstacles to sustainability principles in management schools in more general terms. 
Figure 1 Main barriers to sustainability in management schools

- Lack of material and symbolic resources

- Necessity to hire new professors and/or to insert new sustainability-related content and courses

- Higher education institutions are run as if they were private companies (focused on profiteering)

- Employment of conventional criteria for evaluation (mainly ones related to job market demands)

- Interests established on the status quo

- Careers focused on a unilateral perspective - often underpinned on a branch of neoclassical economic theories in which ecological limits are disregarded

- Absence of a reflexive culture about teaching practices and sharing what is being performed, besides the lack of time to do so

- Competitive relations amid universities; hence, sustainability is taken as a complement instead of an opportunity to rethink programs

- Classroom groups excessively large in quantitative terms

- Lack of physical space/logistics difficulties

- The size of the higher education institutions themselves - normally disproportional and/or seeking rapid growth

- Focus on specific dominant contents

- Focus on a single aspect individuals' thinking rather than settling on more holistic approaches

- Lack of knowledge and confidence from professors about the issue

- Indifference from some professors who believe sustainability is not a relevant topic, thus, they refuse to work with the issue

- Context in which political and media narratives operate as negative strains to sustainability. 
We sustain that these barriers can have their origins traced back to the influence of collective representations transmitted in previous socializations, in the cognitive and conceptual sense of the terms, representations underlined by the influence of neoclassical economic theory, at first. Our argument aligns not only with Bourdieu's and Passeron's idea (1992, 2014) about the role of a formal schooling system in reproducing social structures, but also with Soderbaum (2009) and Murtaza (2011) as these authors emphasized the importance of neoclassical economic thought for management education. In this regard, the idea of self-interested, profit-oriented and gain-maximizing individuals is considered to be key in understanding how social agents in business schools think and act, having been socialized with these principles. It is so, because they indeed were. And once these neoclassical underpinnings became crystalized over time due to various socialization processes, they became integrating and integral dispositions (mental schemes for appreciating, evaluating and acting on the social world) of agents undergoing the formal system of schooling.

Furthermore, this argument has consonance with the one suggested by Ghoshal (2005), who asserted the "obsessive" emphasis university curricula have with the so-called "real world". A world, which, on average, is strictly constrained to the context of private capitalist companies. Interestingly, Bourdieu (2004) affirmed that theories act as a whole construct and are reflected in society through agents' attitudes. Theories might serve as sets of legitimate knowledge, known and renowned, hence loaded with symbolic powers coming from a determined science, which are then reproduced by practices constituting the most diverse social relations.

When a theory about management gains momentum in the mainstream, it is likely to have the effective power to alter managers' behaviors because these agents comply with it. They would obey a theoretical model that presumes, for example, that people are to behave opportunistically, which may induce managerial actions that are more likely to aggravate this kind of behavior than to reduce it (GHOSHAL; MORAN, 1996). In this sense, we also agree with Bourdieu (1991, 1989), who asserted that pedagogical communication performed in formal schooling spaces as universities 
has the practical power of legitimizing and diffusing theoretical models guided by specific and dominated onto-epistemological conceptions. Professors, curricula and contents function as tools of a specific social order to be socially dissimulated and assimilated. These various socialization processes sediment over time and form a habitus.

As previously stated, the logic of social struggles between fields of knowledge, for example, objectifies in the relations pertaining business schools. Thus, the asymmetrical distribution of power and legitimacy that occurs in society between environmental concerns and economic development is likely to be refracted in the web of relations that build up in business schools. Nonetheless, social agents operating in these fields are not unaware or incapable of being reflexive and subvert the dominant logic, but they possess dispositions that may also lead them into acting in a traditional way. By acting according to anterior forms of socialization, agents are likely to have their habitus interweaved by principles of more traditional societal forms like the ones coming from neoclassical economic thought, in which they had been previously socialized.

In addition, the use of criteria and metrics for students and professor might show that interests underscored by the maintenance of the status quo guide business schools. This maintenance is engendered throughout the educational system (BOURDIEU; PASSERON, 1992; BOURDIEU, 2014; BOURDIEU, 1996). This element has the concomitant consequence of making students and organizations foster single-perspective careers based on principles of neoclassical economic thought, neglecting, for example, the ecological limits of economic growth. In this perspective, what stands is the founding ontology of the self-interested, opportunistic and profit-maximizing homo economicus (PALMA, 2015), objectified even in the interactions among schools that compete with one another, neglecting sustainability as a shift in the paradigmatic horizon. In addition, management schools would come to recognize sustainability as just a business differential or a mere complement to their regular activities. Hence, the barriers for sustainability in business schools carry cognitive and structural aspects that foreground the reproductive character they have as part of the formal schooling system. 
Therefore, this conflict between agents' habitus, the in-field struggles and the contents taught in classroom environment are demonstrations of how disinterestedness and disbelief in the principles of sustainability are actually a diachrony between the socialization processes and contents taking place in the classroom and the matrix of dispositions agents bring (their habitus). People do not refuse to teach or learn in pure conscious terms, but they operate through a practical sense guided by what is regarded to be more or less legitimate in the social field in which they are (BOURDIEU, 1996). This dynamic, settled between incorporated social relations (the habitus), the context governed by its own relatively autonomous rules (the field) and the presence of social relations taken as more or less worthy of recognition (capitals) provide an effective explication of why the barriers for sustainability emerge. Not only as a punctual event, but also as a regular phenomenon in the field of management.

In other words, social dynamics contribute significantly to the appearance and operationalization of barriers, whereas individuals also take part in the construction of these obstacles. Previously consolidated political practices, as well as the epistemological and lexical universes, are carried on by agents themselves, actualized over their trajectories, and condition them to establish what is legitimate and recognizable in the most diverse forms of socialization. This underlying logic, which Bourdieu (2004b) applied more directly to the French academic field, is still very pertinent as it can be homologously adapted to investigate the reasons for sustainability ethics facing barriers. 


\section{CONCLUDING REMARKS}

The purpose of this paper is to provide an explanation of the reasons for the emergence of barriers for sustainability in business schools, focusing on the obstacles that are brought about in the social relations between faculty members, students and staff. To do so, we attempted to employ Pierre Bourdieu's conceptual apparatuses for we believe it is still, despite the fact it was elaborated mostly during the 1960 s and 1970 s, quite appropriate to scrutinize and understand the operational mechanisms of continuity and social reproduction serving as fundament for the entire formal schooling system. We comprehend that business schools are not apart from the formal system of education, they are integrating elements of it and, in fact, important ones as they educate future managers for different kinds of organizations.

Our central argument was that these barriers would emerge from a degree of diachrony between students' incorporated mental schemes of perception, evaluations and action on the social world and the principles of sustainability's topic seen in classrooms. Moreover, this diachrony is framed in the relations settled among social agents across the entire field of management, a relatively autonomous social space governed by its own rules. The valid resources of power (whether material or symbolic), legitimate within this field, that is, the capitals, are the elements agents regard as worthy or not.

Taking the mainstream "triple bottom line" as the operational definition, we have stated that due to social relations historically incorporated in their habitus, management students (and also, to some extent, faculty members and staff) experience a kind of diachrony between their mental schemes of perception, evaluation and action towards some practices linked to sustainability and seen in the classroom. As a result, these contents are considered less legitimate and important, especially if compared to ones connected with finance or marketing, for instance. It can be interpreted that the different barriers for sustainability in management schools could emerge precisely from this lack (or even absence) of recognition. 
In this sense, insofar as the principles of sustainability are regarded as less legitimate than the ones from neoclassical economics, students and professors, for example, tend to resist incorporating related norms and prescriptions in their habitus. To summarize, once agents have already incorporated a determined worldview that takes individuals as self-interested, profit-maximizing and opportunistic beings (the neoclassical view), they would be more inclined to understand and learn topics confirming those beliefs.

The contribution we hoped to have given in this paper was not linked with supplying answers to those barriers nor to describe them in depth; our objective was to use an analytical instrument to state why these obstacles appear in the first place. The basis of any critical sociology, like the Bourdieusian one, is not to provide solutions to social phenomena in a functionalist fashion, but to give a scientific outlook to a phenomenon, which means allowing agents to have a clearer understanding of the social structures underpinning their interactions. Hence, future research could try to provide such answers following a more functionalist theoretical perspective or aim at investigating what pragmatic elements actually constitute agents' forms of operationalizing social reproduction in management schools. Because of our objective, we also have not tried to scrutinize how students actually incorporated previous or new schemes of perception, evaluation or action connected with sustainability into their habitus. Therefore, investigating how new schemes could be embodied could be an interesting avenue for future research.

Another compelling alternative is to employ microsociological or individual perspectives, as does Bernard Lahire, who draws on Bourdieu, but moves on to understand the habitus not as a matrix, but like a stock of dispositions to be activated in different contexts. Studying individual trajectories could help to explain why some individuals are more prone to engaging in sustainability practices than others. Furthermore, outlining biographies, for example, could be an interesting way to see how people acquire schemes that recognize some norms and values as more legitimate. 
We conclude by recognizing that sustainability principles such as establishing an equilibrium between economic, social and environmental aspects are an important agenda for the $21^{\text {st }}$ century. Their inclusion in curricula is not without importance and should be disregarded as automatically unfruitful in spite of the argument we brought forth, instead, our attempt here is intended to provoke discussions about the effectiveness of what about and how sustainability is being taught in management schools so it can actually advance towards the objectives its proponents hope to achieve. 


\section{LUIS FELIPE MACHADO DO NASCIMENTO}

\section{REFERENCES}

BARTH, M. Many roads lead to sustainability. A process-oriented analysis of change in higher education. International Journal of Sustainability in Higher Education, v. 1, n. 2, p. 160-175, 2013.

BOURDIEU, P. The forms of capital. In: RICHARDSON, J. G. (Ed.). Handbook of Theory and Research for the Sociology of Education. New York: Greenwood Press, 1985.

BOURDIEU, P. Os três estados do capital cultural. In: NOGUEIRA, M. A.; CATANI, A. (Org.). Escritos de educação. Petrópolis: Vozes, 1998a.

BOURDIEU, P. A escola conservadora. In: NOGUEIRA, M. A.; CATANI, A. Escritos de educação. Petrópolis: Vozes, 1998b.

BOURDIEU, P. Classificação, desclassificação, reclassificação. In: NOGUEIRA, M. A.; CATANI, A. Escritos de educação. Petrópolis: Vozes, 1998c.

BOURDIEU, P. Language and symbolic power. Cambridge: Harvard University Press, 1991.

BORDIEU, P. A distinção: crítica social do julgamento. São Paulo: Edusp; Porto Alegre: Zouk, 2007.

BOURDIEU, P. Razões práticas: sobre a teoria da ação. Campinas: Papirus, 1996.

BOURDIEU, P.; WACQUANT, L. J. D. (Eds.). An invitation to reflexive sociology. Chicago: Chicago University Press, 1992.

BOURDIEU, P.; PASSERON, J.-C. Os Herdeiros: os estudantes e a cultura. Trad. Ione Ribeiro Valle e Nilton Valle. Florianópolis: Editora da UFSC, 2014.

BOURDIEU, P.; PASSERON, J.-C. A reprodução: elementos para uma teoria do sistema de ensino. Rio de Janeiro: Francisco Alves, 1992.

BOURDIEU, P. O poder simbólico. Rio de Janeiro: Difel; 1989.

BOURDIEU, P. Os usos sociais da ciência: por uma sociologia clínica do campo científico. São Paulo: Unesp; 2004.

BOYLE, M. Walking our talk: Business Schools, legitimacy and Citizenship. Business \& Society, v. 43, p. 37-68, 2004.

BRUNSTEIN, J. et al. Assessment and evaluation of higher education in business management: an analysis of a Brazilian case in the light of social learning theory for sustainability. Assessment \& Evaluation in Higher Education, 2015.

ELKINGTON, J. Cannibals with Forks: the Triple Bottom Line of 21st Century Business. BC, Canada: New Society Publishers, Gabriola Island, 1997.

FIGUEIRO, P. Educação para a sustentabilidade em cursos de graduação em administração: proposta de uma estrutura analítica. 2015. 262 f. Tese (Doutorado em Administração) - Escola de Administração, Universidade Federal do Rio Grande do Sul, Porto Alegre. 2015. 
GELI, A.; LEAL FILHO, W. Education for sustainability in university studies: experiences from a project involving European and Latin American universities. International Journal of Sustainability in Higher Education, v. 7, n. 1, p. 81-93, 2006.

GHOSHAL, S. Bad management theories are destroying good management practices. Academy of Management Learning and Education, v. 4, n. 1, p. 75-91, 2005.

GHOSHAL, S.; MORAN, P. Bad for practice: A critique of the transaction cost theory. Academy of Management Review, v. 21, n. 1, p.13-47, 1996.

JABBOUR, C. J. C.; SARKIS, J.; JABBOUR, A. B. L. S.; GOVINDAN, K. Understanding the Process of Greening of Brazilian Business Schools. Journal of Cleaner Production, v. 61, p. 25-35, 2013.

KOPNINA, H.; MEIJERS, F. Education for Sustainable Development (ESD). International Journal of Sustainability in Higher Education, v. 15, p. 2, p. 188-207, 2014.

LOZANO, R. Incorporation and Institutionalization of SD into Universities: Breaking through barriers to change. Journal of Cleaner Production, v. 14, p. 787-796, 2006.

MISOCZKY, M. C. Implicações do uso das formulações sobre campo de poder e ação de Bourdieu nos estudos organizacionais. Revista de Administração Contemporânea, v. 7, n.spe, p. 9-30, 2003.

MURTAZA, N. Pursuing self-interest or self-actualization? From capitalism to a steadystate, wisdom economy. Ecological Economics, v. 70, p. 577-584, 2011.

PALMA, L. Aprendizagem transformadora sustentável: integrando processos de ensinoaprendizagem, gestão e mudança para sustentabilidade nos cursos da área de gestão à luz da teoria da complexidade. 2015. 300 f. Tese (Doutorado em Administração) - Escola de Administração, Universidade Federal do Rio Grande do Sul, Porto Alegre. 2015.

ROHWEDER, L. Integrating Environmental Education Into Business Schools' Educational Plans in Finland. GeoJournal, v. 60, n. 2, p. 175-181, 2004.

SCHUTEL, S. Aprendizagem transformadora para o desenvolvimento sustentável futuro: estudo de casos em cursos de administração no Canadá e no Brasil. 2015. $274 \mathrm{f}$. Tese (Doutorado em Administração) - Escola de Administração, Universidade Federal do Rio Grande do Sul, Porto Alegre. 2015.

SODERBAUM, P. Making Actors, Paradigms and Ideologies Visible in Governance for Sustainability. Sustainable Development, v.17, p.70-81, 2009.

STUBBS, W.; COCKLIN, C. Teaching sustainability to business students: shifting mindsets. International Journal of Sustainability in Higher Education, v. 9, n. 3, p. 206-221, 2008.

TIANA, S.A.; MORILLA, M. F.; CARRERA, J. M. M.; RAMENTOL, S.V. Barreras para la sustentabilidad integral en la Universidad. Revista Iberoamericana de Educación, v. 73, n. 1, p. 253-272, 2017.

WARBURTON, K. Deep learning and education for sustainability. International Journal of Sustainability in Higher Education, v. 4, n. 1, p. 44-56, 2003. 


\section{DADOS DOS AUTORES}

\section{BRUNO DE SOUZA LESSA brunolessa85@yahoo.com.br}

\section{Mestre em Administração pela UFRGS}

Instituição de vinculação: Universidade Federal do Rio Grande do Sul Porto Alegre/RS - Brasil

Áreas de interesse em pesquisa: Administração; Ciências Sociais; Sociologia dos Indivíduos.

^Rua José do Patrocínio, 408, ap. 102 Cidade Baixa Porto Alegre/RS 90050-001

\section{KELLY FABIANE SPIER kellyfspier@gmail.com}

Doutoranda em Gestão de Pessoas e Relações de Trabalho pela UFRGS

Instituição de vinculação: Universidade Federal do Rio Grande do Sul

Porto Alegre/RS - Brasil

Áreas de interesse em pesquisa: Sustentabilidade; Educação Sustentável e Aprendizagem nas Organizações.

\section{LUIS FELIPE MACHADO DO NASCIMENTO nascimentolf@gmail.com Doutor em Administração pela UFRGS}

Instituição de vinculação: Universidade Federal do Rio Grande do Sul Porto Alegre/RS - Brasil

Áreas de interesse em pesquisa: Educação para Sustentabilidade, Sustentabilidade, Sustainable Suppy Chain. 